\title{
OPEN
}

\section{Publisher Correction: A thirteen- million-year divergence between two lineages of Indonesian coelacanths}

\author{
Kadarusman, HagiYulia Sugeha, Laurent Pouyaud, Régis Hocdé (D, \\ Intanurfemi B. Hismayasari, Endang Gunaisah, Santoso B. Widiarto, Gulam Arafat, \\ Ferliana Widyasari, David Mouillot \& Emmanuel Paradis $\mathbb{D}$
}

Correction to: Scientific Reports https://doi.org/10.1038/s41598-019-57042-1, published online 13 January 2020

In the original version of this Article, Figure 1 contained an error where Northeastern Australia was omitted.

In addition, there was a typographical error in Affiliation 5, which was incorrectly given as 'MARBEC, Univ Montpellier, IRD, Ifremer, CNRS, Montpellier, France'. The correct affiliation is listed below:

MARBEC, Univ Montpellier, CNRS, Ifremer, IRD, Montpellier, France

These errors have now been corrected in the HTML and PDF versions of the Article.

(1) Open Access This article is licensed under a Creative Commons Attribution 4.0 International License, which permits use, sharing, adaptation, distribution and reproduction in any medium or format, as long as you give appropriate credit to the original author(s) and the source, provide a link to the Creative Commons license, and indicate if changes were made. The images or other third party material in this article are included in the article's Creative Commons license, unless indicated otherwise in a credit line to the material. If material is not included in the article's Creative Commons license and your intended use is not permitted by statutory regulation or exceeds the permitted use, you will need to obtain permission directly from the copyright holder. To view a copy of this license, visit http://creativecommons.org/licenses/by/4.0/.

(C) The Author(s) 2020 